\title{
Monetary Policy and Asset Prices
}

Nearly seven years have passed since the last recession ended in November 2001. That recession was characterized by an unwinding of excess business investment in the aftermath of a burst U.S. stock market bubble (see Lansing 2003a). During the early years of the recovery, an accommodative interest rate environment provided stimulus to the housing market. To keep initial monthly payments affordable for the large influx of new and often credit-impaired homebuyers, the lending industry marketed a range of "exotic" mortgage products, for example, loans requiring no down payment or documentation of income, monthly payments for interest-only or less, and adjustable rate mortgages with low introductory "teaser" rates that reset higher over time. House prices rose faster in areas where exotic mortgages were more prevalent (see Tal 2006), suggesting, ironically, that the new lending products may have actually harmed affordability by fueling the price run-up.

From 2001 to 2006, house prices rose much faster than the underlying fundamentals, as measured by rents or household income. Equity extracted from rapidly appreciating real estate yielded hundreds of billions of dollars per year in spendable cash for households, providing significant support for U.S. consumption. The consumption boom was accompanied by a parabolic rise in household debt relative to income and a decline in the personal saving rate (see Lansing 2005).

House prices peaked in 2006 and have since reversed course dramatically. The bursting of the housing bubble has been followed by a sharp rise in delinquencies and foreclosures, massive write-downs in the value of mortgage-backed securities and derivatives, the collapse of a number of large financial institutions, and, most recently, a serious financial crisis prompting unprecedented government intervention in U.S. private capital markets.

An important unsettled question in economics is whether policymakers should take deliberate steps to prevent or deflate asset price bubbles (see Lansing 2003b). Those who advocate leaning against bubbles point out that excessive asset prices can distort economic and financial decisions, creating costly problems that can take many years to dissipate. Others argue that it is difficult for policymakers to detect a bubble in real time, and that policies intended to prick a suspected bubble could send the economy into a recession, thereby forgoing the benefits of the boom that might otherwise continue.

In light of the severe economic fall-out from recent bubble episodes, this Economic Letter examines the potential role of monetary policy in responding to asset prices.

\section{Monetary policy and the Taylor rule}

Central banks' goals are to keep inflation low while promoting sustainable growth and full employment. Policymaker behavior is typically modeled in the form of a "Taylor rule," whereby a short-term nominal interest rate (the federal funds rate) is adjusted in response to inflation and some measure of real economic activity. Using such a framework, Taylor (1999) shows that estimated versions of the Fed's policy rule can help account for the "Great Inflation" of the 1970s and the period of good economic performance in the 1980s and 1990s. Specifically, he finds that the estimated response of the federal funds rate to inflation in the 1970s is smaller than the estimated response in the 1980s and 1990s. In retrospect, it appears that the "policy mistake" of the 1970s was that the funds rate remained too low for too long as inflation continued to rise. Taylor (2007) extends this type of analysis to more recent Fed policy actions. He concludes that, from 2003 to 2006, "the federal funds rate was well below what experience during the previous two decades of good economic performance... would have predicted."

Figure 1 plots an estimated version of the Taylor rule using monthly data from January 1987 to September 2008. The estimated rule is constructed by regressing the federal funds rate on a constant, the 12-month percent change in the core personal consumption expenditures price index, and the unemployment gap, i.e., the percentage point difference between the natural rate of unemployment and the prevailing unemployment rate. The natural rate series is constructed by the Congressional Budget Office.

The figure shows that the estimated rule does a good job of accounting for broad movements in the actual funds rate over the past two decades. However, the actual funds rate is consistently above the estimated rule from 1995 to 1998, and consistently below the estimated rule from 2003 to 2008. Focusing on the 


\section{Figure 1}

\section{Estimated policy rule}

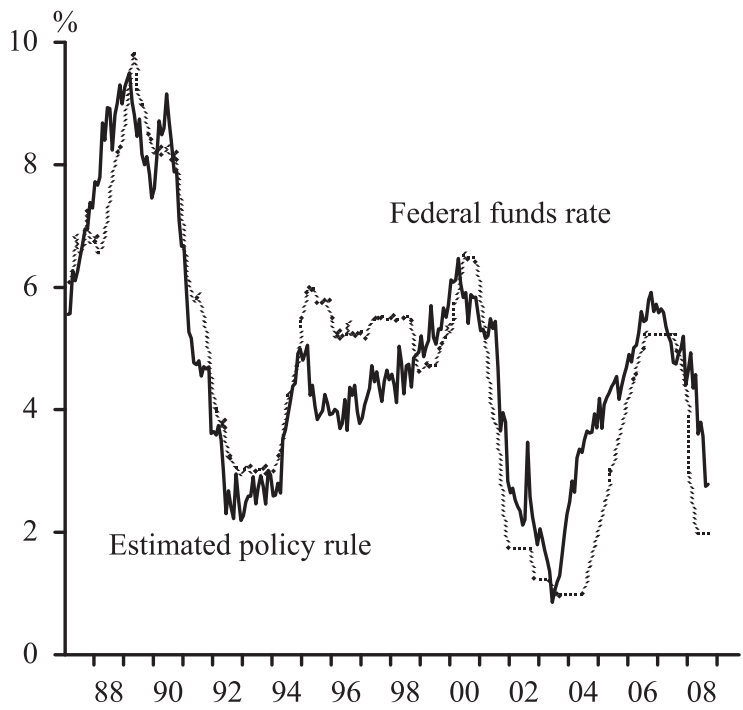

latter period, the threat of deflation following the bursting of the stock market bubble was cited at the time as justification for the low level of the funds rate in 2003. Taylor (2007) uses a statistical model of new housing starts to argue that the deviation of the funds rate below the path predicted by previous Fed policy behavior contributed to the housing boom. Moreover, he argues that even after the funds rate started rising in 2004, long-term interest rates remained low because the bond market perceived that the Fed's response to inflation had permanently shifted. According to Taylor, a higher funds rate path would have avoided much of the housing boom, such that the subsequent reversal and resulting financial market turmoil would have been less severe.

\section{The Taylor rule augmented}

\section{with stock market variables}

If stock market investors react to the same observations about the economy as do policymakers, then special factors that are relevant to monetary policy, such as the threat of deflation in 2003 or the recent financial crisis, can perhaps be captured by observed movements in stock prices. Along these lines, Figure 2 plots an augmented version of the estimated policy rule that includes two additional explanatory variables: (1) the percentage change in the S\&P 500 stock index over the prior 12 months, and (2) the prior-month level of the S\&P 500 stock index. As in Lansing (2003b), the use of data from prior months helps ensure that the direction of causation runs from the stock market to the funds rate, and not vice versa. The figure shows that the inclusion of the stock market variables significantly improves the fit of the estimated rule, particularly from 2006
Figure 2

Estimated policy rule with stock market variables

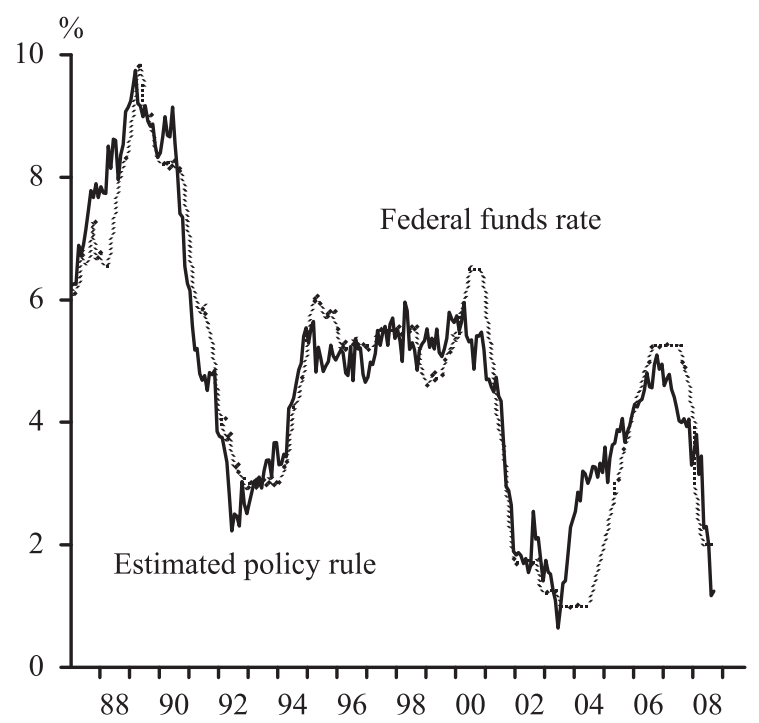

through the end of the data sample in September 2008. However, even after controlling for special factors that show up in stock prices, the actual funds rate path continues to deviate below the estimated policy rule path from 2003 to 2005 .

\section{Should monetary policy lean against bubbles?}

It remains controversial whether a higher funds rate path from 2003 onwards could have prevented the housing bubble and its subsequent fallout. More generally, there is a wide range of views about whether central banks should take deliberate steps to prevent or deflate asset price bubbles.

One view, summarized by former Fed Chairman Greenspan (2004), is that central banks should not attempt to prick a suspected bubble, but rather they should follow a "strategy of addressing the bubble's consequences rather than the bubble itself." This view is predicated on the idea that it is difficult for policymakers to identify a bubble in real time. Others have countered that central banks already respond to economic variables that are difficult to measure in real time, such as the level of potential GDP. Moreover, Borio and Lowe (2002) argue that bubbles can be identified in real time if central banks expand their view beyond asset prices to include other variables that signal a threat to financial stability. In an exhaustive historical study of financial market bubbles in many countries, they find that episodes of sustained rapid credit expansion, booming stock or house prices, and high levels of investment are almost always followed by periods of stress in the financial system. According to the authors, "If the economy is indeed robust and the boom is 
sustainable, actions by the authorities to restrain the boom are unlikely to derail it altogether. By contrast, failure to act could have much more damaging consequences, as the imbalances unravel" (p. 26).

\section{Regulatory policy and bubbles}

Beyond the setting of short-term nominal interest rates, a broader view of monetary policy includes regulatory oversight of financial institutions. Throughout history, asset price bubbles have typically coincided with outbreaks of fraud and scandal, followed by calls for more regulation once the bubble has burst (see Gerding 2006). Recent bubble episodes are no different. If a goal of financial regulation is to prevent fraud, and as history attests, asset price bubbles are typically associated with fraud, then one could argue that financial regulators at central banks should strive to prevent bubbles.

According to Mishkin (2008), financial regulators at central banks may have a greater likelihood of identifying a credit-fueled bubble in real time because "they might have information that lenders have weakened their underwriting standards and that credit extension is rising at abnormally high rates." He argues that "financial developments might then lead policymakers to consider implementing policies to... help reduce the magnitude of the bubble." During the recent housing bubble, underwriting standards were weakened and credit extension did rise at abnormally high rates, resulting in rapid growth of subprime mortgage lending. In the aftermath of the burst housing bubble, financial regulators are now taking steps to strengthen the integrity of underwriting, appraisal, and credit-rating procedures.

\section{Conclusion}

In the years following the 2001 recession, the booming U.S. housing market was a powerful stimulating force for the U.S. economy. Consumers extracted equity from their homes to pay for all kinds of goods and services, while the personal saving rate approached zero. Hundreds of thousands of new jobs were created in residential construction, mortgage banking, and real estate. Ample liquidity and easy lending practices drew in waves of new buyers who had previously been shut out of the housing market. Strong demand for starter homes allowed existing owners to move up to bigger houses with bigger mortgages. The reversal of this stimulus is now exerting a significant drag on household spending, employment, and GDP growth.

The painful unwinding of bubble-induced excesses, first with the U.S. stock market in the early 2000s, and now with the U.S. housing market, has spurred debate about the appropriate response of monetary policy to asset price movements - either on the upswing or the downswing. Important unsettled questions remain about whether central banks should lean against asset price bubbles and the degree to which central banks should attempt to mitigate the economic fallout from speculative losses. In any case, further research on the links between monetary policy and asset prices is needed.

\section{Kevin J. Lansing Senior Economist}

\section{References}

[URLs accessed October 2008.]

Borio, C., and P. Lowe. 2002. "Asset Prices, Financial and Monetary Stability: Exploring the Nexus." Bank for International Settlements Working Paper 114. http://www.bis.org/publ/work114.htm

Gerding, E.F. 2006. "The Next Epidemic: Bubbles and the Growth and Decay of Securities Regulation." Connecticut Law Review 38(3), pp. 393-453.

Greenspan, A. 2004. "Risk and Uncertainty in Monetary Policy." American Economic Review Papers and Proceedings 94, pp. 33-40.

Lansing, K.J. 2003a. "Growth in the Post-Bubble Economy" FRBSF Economic Letter 2003-17 (June 20). http://www.frbsf.org/publications/economics/ letter/2003/el2003-17.html

Lansing, K.J. 2003b. "Should the Fed React to the Stock Market?” FRBSF Economic Letter 2003-34 (November 14). http://www.frbsf.org/publications/ economics/letter/2003/el2003-34.html

Lansing, K.J. 2005. "Spendthrift Nation." FRBSF Economic Letter 2005-30 (November 10). http://www.frbsf.org/publications/economics/ letter/2005/el2005-30.html

Mishkin, F.S. 2008. "How Should We Respond to Asset Price Bubbles?" Speech at the Wharton Financial Institutions Center, Philadelphia (May 15). http://www.federalreserve.gov/newsevents/ speech/mishkin20080515a.htm

Tal, B. 2006. "How Painful Will Mortgage Resets Be?” CIBC World Markets, Inc., Consumer Watch U.S. (October 18). http://research.cibcwm.com/ economic_public/download/cwus-102006.pdf

Taylor, J.B. 1999. "A Historical Analysis of Monetary Policy Rules.” In Monetary Policy Rules, ed. J.B. Taylor. Chicago: University of Chicago Press, pp. 319-341.

Taylor, J.B. 2007. "Housing and Monetary Policy," Remarks at Symposium Sponsored by Federal Reserve Bank of Kansas City, Jackson Hole, Wyoming (September 1). http://www. kansascityfed.org/PUBLICAT/SYMPOS/2007/ PDF/2007.09.04.Taylor.pdf 
P.O. Box 7702

San Francisco, Calif.

San Francisco, CA 94120

\section{Address Service Requested}

Are Global Imbalances Due to Financial Underdevelopment...?

The Financial Markets, Housing, and the Economy

Small Business Lending and Bank Competition

Retirement Savings and Decision Errors: Lessons from Behavioral...

Did Large Recalls of Chinese Consumer Goods Lower U.S. Imports...?

Speculative Bubbles and Overreaction to Technological Innovation

Consumer Sentiment and Consumer Spending

Research on the Effects of Fiscal Stimulus: Symposium Summary

Monetary Policy and Asset Markets: Conference Summary

Can Young Americans Compete in a Global Economy?

Unanchored Expectations? Interpreting the Evidence from Inflation...

How and Why Does Age at Kindergarten Entry Matter?

Treasury Bond Yields and Long-Run Inflation Expectations

Regional Variation in the Potential Economic Effects of Climate...

Summer Reading: New Research in Applied Microeconomics...

The U.S. Economic Situation and the Challenges for Monetary Policy

The EMU Effect on the Currency Denomination of International Bonds

Oil Prices and Inflation

Sectoral Reallocation and Unemployment

What Is Liquidity Risk?
Valderrama

Yellen

Laderman

Armour/Daly

Candelaria/Hale

Lansing

Wilcox

Wilson

Dennis

Cascio

Huang/Trehan

Cascio

Christensen

Butsic/Hanak/Valletta

Doms

Yellen

Hale/Spiegel

Cavallo

Valletta/Cleary

Lopez

Opinions expressed in the Economic Letter do not necessarily reflect the views of the management of the Federal Reserve Bank of San Francisco or of the Board of Governors of the Federal Reserve System. This publication is edited by Judith Goff, with the assistance of Anita Todd. Permission to reprint portions of articles or whole articles must be obtained in writing. Permission to photocopy is unrestricted. Please send editorial comments and requests for subscriptions, back copies, address changes, and reprint permission to: Public Information Department, Federal Reserve Bank of San Francisco, P.O. Box 7702, San Francisco, CA 94120, phone (415) 974-2163, fax (415) 974-3341, e-mail sf.pubs@sf.frb.org. The Economic Letter and other publications and information are available on our website, http://www.frbsf.org. 